\title{
THE INFLUENCE OF LOW TEMPERATURES DURING BLOOMING IN FRUIT GROWING TREES SPECIES
}

\author{
Elena Iurea $^{1}$, Simona-Mihaela Chelaru ${ }^{1 *}$, Mădălina-Iuliana Gherghel ${ }^{1}$, Sorina Sîrbu ${ }^{1}$, \\ Cristina-Ionela Turcu ${ }^{1}$, Ionuț -Vasile Ungureanu ${ }^{1}$, Ionel Perju ${ }^{1}$ \\ ${ }^{1}$ Research Station for Fruit Growing Iaşi, Romania
}

\begin{abstract}
The evolution of the phenological stages of the fruit trees species is directly influenced by the climatic conditions so that the period is different from one species to another. The studies were carried out within the Research Station for Fruit Growing Iassi, in the research fields for the main fruit tree species for the period 2018-2020. Unfavourable weather conditions during the flowering period led to damage to the viability of the buds, especially to the stone species due to the late spring frosts, which directly affected fruit production. In particular, apricots, peaches and sweet cherries suffered considerable losses. The results of the studies highlight the importance of resistance to extreme conditions of each species depending on the characteristics inherited from the biological parents.
\end{abstract}

Keywords: buds, flowers, frost, trees species, viability.

\section{INTRODUCTION}

The development of fruit-growing trees crops, which is particularly significant for the national economy is conditioned by a series of factors that are favourable to the surrounding environment, among which the temperature has a determining role. The temperature determines the development of all the vital processes of the trees, having at the same time a limiting effect on the spreading of a species among zones (Milică et al., 1982). The temperatures, both low and high, represent a biological necessity of each species, determined by genotype, the values that exceed minimum and maximum temperature limits necessary for the development of particular phenophases leading to the destruction of plant parts (different in stage), sometimes to the destruction of the entire plant (Botu et al., 2001; Cociu, 2007). The most critical period in fruit-growing trees species is the one preceding and following the bloom, when the fruit-growing trees sensibility is maximum (Budan and Grădinaru, 2000; Rodrigo, 2000; Long, 2013).

In the North-Estern area of Romania, in the last five years, frosts occur frequently in April, coinciding with this critical period. The paper presents aspects regarding the influence of low temperatures during the bloom period in fruit-growing species, in the Iasi area.

\section{MATERIALS AND METHODS}

The studies were performed between 2018 - 2020, using seven fruit-growing trees species as research material (apricot, peach, sweet cherry, sour cherry, plum, apple and walnut), all of them 


\section{Current Trends in Natural Sciences}

Vol. 9, Issue 17, pp. 341-345, 2020

https://doi.org/10.47068/ctns.2020.v9i17.043

Current Trends in Natural Sciences (on-line)

ISSN: 2284-953X

Current Trends in Natural Sciences (CD-Rom)

ISSN: 2284-9521

ISSN-L: 2284-9521

ISSN-L: 2284-9521

being found in the competition crops located in the experimental polygon from RSFG Iaşi. The technology particular to every species was done. The degree of damage for the generative organs was established by sectioning the flowers (100 buds/flowers from every third of the crown for each variant-species) and by correlating the air temperature with the phenophase reached by the fruitgrowing trees species when the frost came. The average percentage of buds/flowers with illnesses for the studied species was calculated by averaging the number of samples affected at the three height levels.

Climatically, the second half of March 2019 and 2020 recorded negative temperatures between 2.2 to $-4.9^{\circ} \mathrm{C}$ (time period when the apricot and peach tree were in the blooming phase) and the first days of April 2020 recorded negative temperatures between -1.3 to $-5.9^{\circ} \mathrm{C}$ (time period when the cherry tree was in the blooming phenophase) (table 1; figure 1).

Table 1. The air temperature recorded in the first four months of the year (Iaşi-Romania area, 2018-2020)

\begin{tabular}{|c|c|c|c|c|c|c|}
\hline \multicolumn{3}{|c|}{ Month } & \multirow{2}{*}{$\begin{array}{c}\text { January } \\
-1.9 \\
\end{array}$} & \multirow{2}{*}{$\begin{array}{c}\text { February } \\
-1.2 \\
\end{array}$} & \multirow{2}{*}{$\begin{array}{l}\text { March } \\
4.7 \\
\end{array}$} & \multirow{2}{*}{$\begin{array}{l}\text { April } \\
11.4\end{array}$} \\
\hline \multirow{13}{*}{$\begin{array}{c}\text { Air Temperature } \\
\left({ }^{\circ} \mathrm{C}\right)\end{array}$} & Mu & $\begin{array}{l}\text { nual average } \\
05-2015 \text { ) }\end{array}$ & & & & \\
\hline & \multirow{4}{*}{2018} & Minimum value & -14.4 & -18.4 & -17.0 & 1.5 \\
\hline & & Maximum value & 9.9 & 10.5 & 18.6 & 29.5 \\
\hline & & Monthly average & -1.2 & -2.0 & 1.1 & 15.3 \\
\hline & & Deviation & -0.7 & -0.8 & -3.6 & 3.9 \\
\hline & \multirow{4}{*}{2019} & Minimum value & -14.8 & -8.5 & -6.2 & 0.3 \\
\hline & & Maximum value & 10.1 & 17.6 & 23.2 & 26.3 \\
\hline & & Monthly average & -3.0 & 1.9 & 7.4 & 10.5 \\
\hline & & Deviation & -11.4 & -16.5 & -9.6 & -0.9 \\
\hline & \multirow{4}{*}{2020} & Minimum value & -8.4 & -7.8 & -4.9 & -5.9 \\
\hline & & Maximum value & 13.5 & 17.9 & 19.8 & 26.1 \\
\hline & & Monthly average & 0.9 & 4.2 & 7.6 & 11.5 \\
\hline & & Deviation & -1.0 & 3.0 & -9.4 & 0.1 \\
\hline
\end{tabular}

The experimental data was interpreted statistically by analysing the variance.

\section{RESULTS AND DISCUSSIONS}

Besides the hereditary traits that all the fruit-growing trees species possess, the clime and technology elements act simultaneously on the biological processes. Under the presented conditions, the studied fruit-growing trees species encountered negative temperatures in the phenophases between the buds swelling and the full bloom. After sectioning the flowering buds before bloom and in full bloom, gynoecium damage was noticed at the level of the ovary and style and it was highlighted by their drying (figure 2).

The evolution of the phenological stages of the trees is directly influenced by the climatic conditions, the time period being sequenced differently between species (Ansari and Davarynejad, 2008; Chmielewski et al., 2004). The vegetative period begins with the buds swelling and it ends with the fall of the leaves, evolving on a different time period based on the species. The beginning of the vegetation period (the buds swelling) for the seven studied fruit-growing trees species between 2018-2020 was recorded the earliest for the apricot and peach species on February $07^{\text {th }}$ 2020 and the latest for the sour cherry species on March $30^{\text {th }} 2018$ (table 2). The bloom started the earliest in apricot and peach trees between March $15^{\text {th }}-26^{\text {th }} 2020$, followed by sweet cherry, sour 


\section{Current Trends in Natural Sciences}

Vol. 9, Issue 17, pp. 341-345, 2020

https://doi.org/10.47068/ctns.2020.v9i17.043

Current Trends in Natural Sciences (on-line)

ISSN: 2284-953X

Current Trends in Natural Sciences (CD-Rom)

ISSN: 2284-9521

ISSN-L: 2284-9521

ISSN-L: 2284-9521

cherry, plum, apple and walnut trees and it ended between March $28^{\text {th }} 2020$ (apricot tree) and May $07^{\text {th }} 2020$ (walnut tree, female flowers).

In 2020, the trigger of buds swelling and bloom stages was earlier than 2018 and 2019. The higher the temperatures get, the earlier the bloom gets triggered.
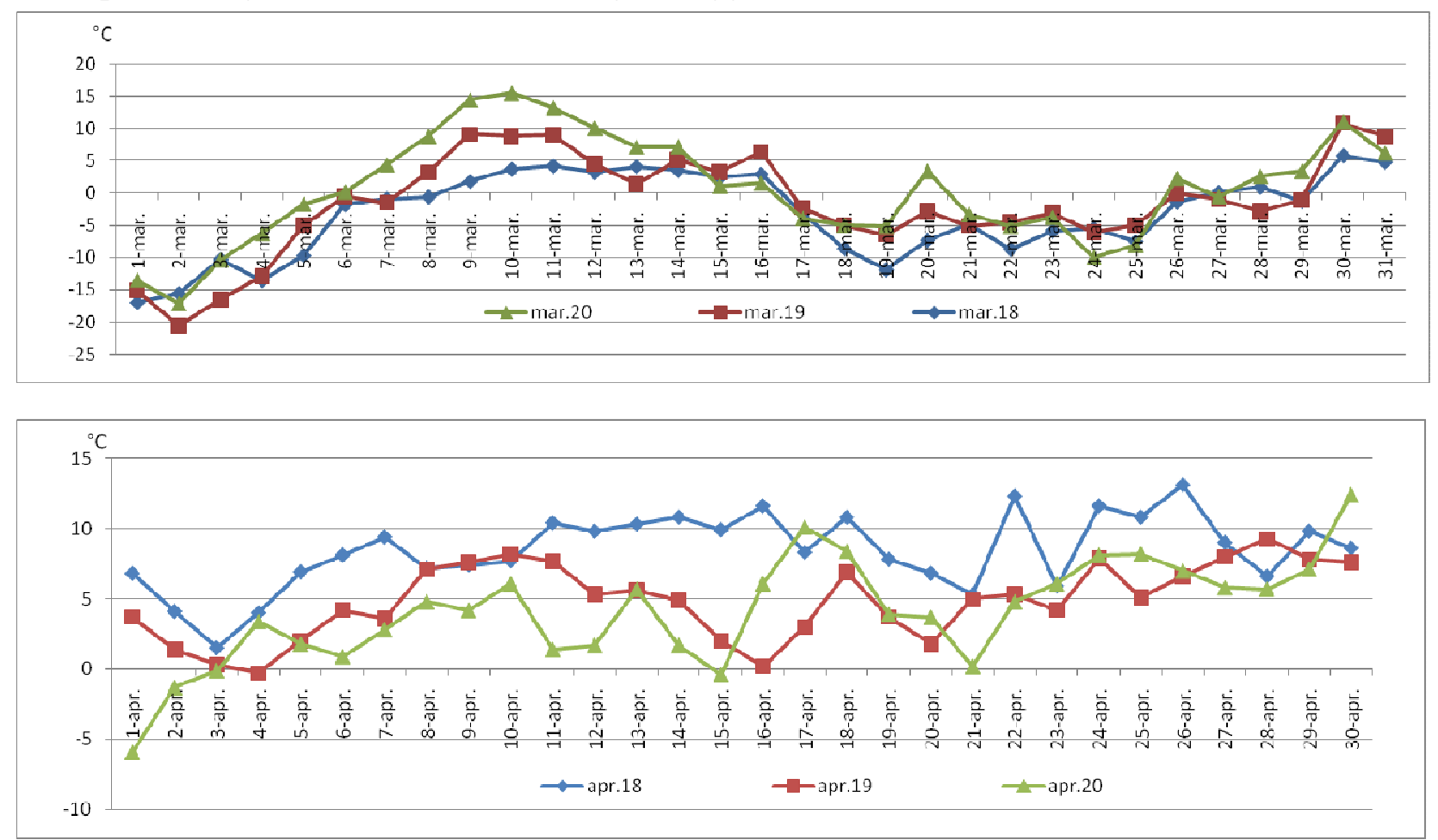

Figure 1. Minimum temperatures evolutions recorded between March-April (Iaşi-Romania area, 2018-2020)

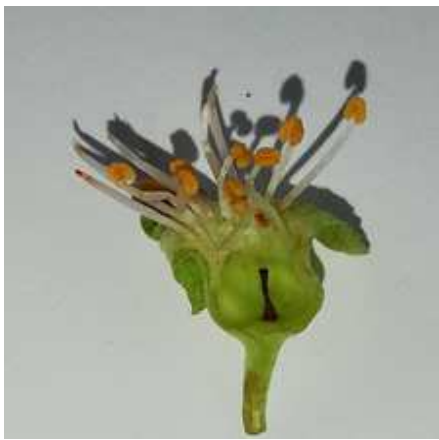

a.

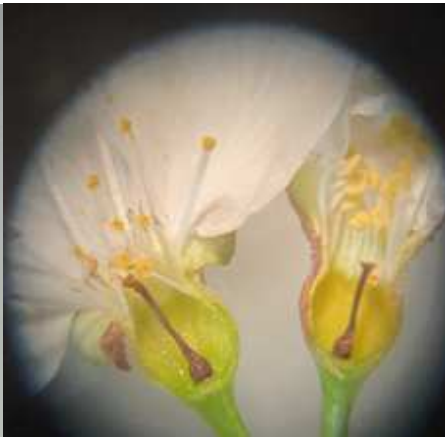

b.

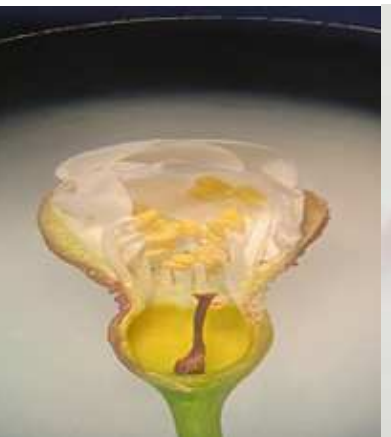

c.

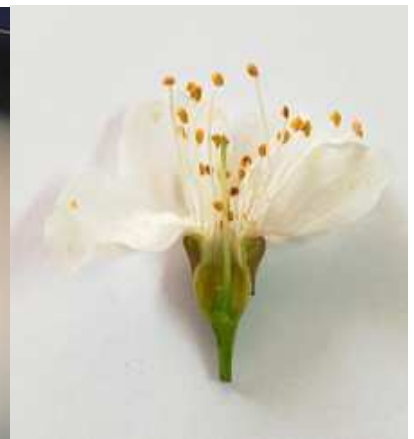

d.

Figure 2. Aspects with the gynoecium in cherry flowers ( $a, b, c-d r y$ ovary and style); $d$-viable ovary and style 
Table 2. The development of the fructification phenophases in seven fruit-growing trees species (RSFG Iasi; 2018-2020)

\begin{tabular}{|c|c|c|c|c|c|c|c|c|c|c|c|c|}
\hline \multirow[t]{2}{*}{ Species } & \multicolumn{3}{|c|}{$\begin{array}{c}\text { Buds swelling } \\
\text { (date) }\end{array}$} & \multicolumn{3}{|c|}{$\begin{array}{c}\text { Bud opening } \\
\text { (date) }\end{array}$} & \multicolumn{3}{|c|}{$\begin{array}{c}\text { Bloom beginning } \\
\text { (date) }\end{array}$} & \multicolumn{3}{|c|}{$\begin{array}{c}\text { Bloom end } \\
\text { (date) }\end{array}$} \\
\hline & 2018 & 2019 & 2020 & 2018 & 2019 & 2020 & 2018 & 2019 & 2020 & 2018 & 2019 & 2020 \\
\hline \multicolumn{13}{|c|}{ Limit dates (the earliest in the buds swelling phenophase - the latest in the bloom end phenophase) } \\
\hline Apricot tree & 24.03 & 06.03 & 17.02 & 04.04 & 18.03 & 07.03 & 08.04 & 24.03 & 15.03 & 16.04 & 10.04 & 28.03 \\
\hline Peach tree & 20.03 & 11.03 & 17.02 & 30.04 & 30.03 & 07.03 & 10.04 & 09.04 & 26.03 & 16.04 & 25.04 & 09.04 \\
\hline Cherry tree & 27.03 & 10.03 & 07.03 & 04.04 & 20.03 & 20.03 & 09.04 & 06.04 & 31.03 & 23.04 & 28.04 & 26.04 \\
\hline $\begin{array}{l}\text { Sour cherry } \\
\text { tree }\end{array}$ & 30.03 & 06.03 & 07.03 & 04.04 & 18.03 & 18.03 & 10.04 & 08.04 & 07.04 & 25.04 & 01.05 & 01.05 \\
\hline Plum tree & 04.04 & 12.03 & 07.03 & 03.04 & 21.03 & 12.03 & 09.04 & 10.04 & 28.03 & 20.04 & 24.04 & 20.04 \\
\hline Apple tree & 06.03 & 06.03 & 06.03 & 11.04 & 11.03 & 18.03 & 16.04 & 17.04 & 11.04 & 26.04 & 03.05 & 26.04 \\
\hline $\begin{array}{c}\text { Walnut tree } \\
\text { flower } \hat{\partial}^{\lambda}\end{array}$ & 2303 & 2600 & 2003 & 0704 & 3003 & 05 & 27.04 & 09.04 & 19.04 & 03.05 & 17.04 & 05.05 \\
\hline $\begin{array}{l}\text { Walnut tree } \\
\text { flower }+9\end{array}$ & 20.00 & 20.03 & 20.05 & 01.04 & 0.00 & 0.04 & 27.04 & 07.04 & 17.04 & 03.05 & 20.04 & 07.05 \\
\hline
\end{tabular}

The adverse meteorological conditions during the vegetation period (buds swelling - bloom) led to damage in the viability of the generative organs especially for the stony species following the late spring frosts that affected directly the fruits production. The apricot, peach and cherry trees in particular recorded significant loss. The data in table 3 highlights that the degree of damage of the generative organs varies between species.

Analysing the average values over three years (2018-2020), it was noticed statistically that the apricot tree species (46.3\%) recorded positive significant differences in comparison with the average of the studied fruit-growing trees $(15.1 \%)$ and the plum and apple trees presented the best resistance, but with non-significant statistical values in comparison to the average of the studied species.

Based on the degree of damage of the generative organs that was observed during the three years of study, it can be noticed that in 2018, the apricot and peach trees were the most affected (69\% and $11 \%$ ) because they were in the buds swelling stage and the minimum temperature recorded negative values between $-7.3^{\circ} \mathrm{C}$ (at March $20^{\text {th }}$ in 2018) and $-5.5^{\circ} \mathrm{C}$ (at March $24^{\text {th }}$ in 2018). These results are in accordance to other similar studies regarding fruit-growing trees sensitivity to low temperatures during the vegetation period (Murray, 2011). In 2019, the cherry tree and apricot tree species were the most affected in proportion of $62 \%$ and respectively $15 \%$ (table 3 ), finding themselves in the buds swelling (apricot start at March $06^{\text {th }}$ in 2019) or even buds opening phenophases (sweet cherry start at March $20^{\text {th }}$ in 2019), the minimum recorded temperatures being between $-2.7^{\circ} \mathrm{C}$ and $-3.7^{\circ} \mathrm{C}$. In 2020 , in the first day of April, the minimum temperature was $-5.9^{\circ} \mathrm{C}$, value that exceeded the resistance threshold of the buds, flowers and young fruits.

Thus, the apricot tree (55\%) was affected the most, finding itself in the stage of fruit set, followed by the sweet cherry tree (30\%) which was in the full bloom phenophase, sour cherry (28\%), which was in the beginning of bloom phenophase, the peach tree $(23 \%)$ which was in the stage of fruit set and the walnut tree (13\%) finding itself in the opening bud phenophase (table 3 ). 
Table 3. The degree of damage of the generative organs in seven species of fruit-growing trees (RSFG Iasi; 2018-2020)

Resistance to frost of the generative organs in the buds swelling and bloom phenophases (\% damaged buds/flowers)

\begin{tabular}{|c|c|c|c|c|c|c|}
\hline \multirow[b]{2}{*}{ Species } & \\
\hline & 2018 & 2019 & 2020 & Average & $\begin{array}{c}\text { The difference } \\
\text { in comparison } \\
\text { with the } \\
\text { variants } \\
\text { average }\end{array}$ & Significance $^{1}$ \\
\hline Apricot & 69 & 15 & 55 & 46.3 & +31.2 & $*$ \\
\hline Peach & 11 & 0 & 23 & 11.3 & -3.8 & ns \\
\hline Cherry & 5 & 62 & 30 & 32.3 & +17.2 & ns \\
\hline Sour cherry & 0 & 6 & 28 & 11.3 & -3.8 & ns \\
\hline Plum & 0 & 0 & 0 & 0 & -15.1 & ns \\
\hline Apple & 0 & 0 & 0 & 0 & -15.1 & ns \\
\hline Walnut & 0 & 0 & 13 & 4.3 & -10.8 & $\mathrm{~ns}$ \\
\hline X (Average) & 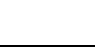 & & & 15.1 & - & - \\
\hline
\end{tabular}

\section{CONCLUSIONS}

In the Northestern area of Romania, during the last years, the second half of March and the first half of April have been facing frequently minimum temperatures below the biological threshold of resistance for apricot, peach, sweet cherry and sour cherry trees, reducing fully or partially the production of fruits.

The degree of damage of the generative organs in the studied species, between $0-46.3 \%$ was determined by their genetic resistance.

The species that tolerated the low temperatures extremely well are the plum and apple trees.

\section{ACKNOWLEDGEMENTS}

This study has been partially financed by the Ministry of Agriculture and Rural Development, Grant No. ADER 7.2.2. /2019, with title 'Implementing new methods for breeding fruit tree species for the efficiency and reduce time of the selection process'.

\section{REFERENCES}

Ansari, M., Davarynejad, G. (2008). The Flower Phenology of Sour Cherry Cultivars. American-Eurasian J. Agric. \& Environ. Sci., 4 (1), 117-124.

Botu, I., Botu, M., Achim, G. (2001). Cultura nucului în exploatații nucicole moderne [Walnut cultivation in modern walnut farms]. Ed. Phoenix, Braşov.

Budan, S., Grădinaru, G. (2000). Cireşul [Cherry tree]. Ed. Ion Ionescu de la Brad, Iaşi, 262 pp.

Chmielewski, F.-M., Müller, A., Bruns, E. (2004). Climate changes and trends in phenology of fruit trees and field crops in Germany, 1961-2000. Agricultural and Forest Meteorology 121, 69-78.

Cociu, V. (2007). Nucul, alunul, migdalul [Walnut, hazelnut, almond], Editura M.A.S.T. , Bucureşti, 270 pp.

Long, L. (2013). Fruit Bud Hardiness. Good Fruit Grower. Available at https://www.goodfruit.com/how-the-coldaffects-fruit-buds/

Milică, C.I., Dorobanțu, N., Nedelcu, P., Baia, V., Suciu, T., Popescu, F.,Teşu, V., Molea, I. (1982). Fiziologie vegetală [Plant physiology], Editura Didactică şi Pedagogică, Bucureşti, 375 pp.

Murray, M. (2011). Critical Temperatures for Frost Damage on Fruit Trees, IPM-012-11, Utah Pests Fact Sheet, Utah State, SUA, p. 2.

Rodrigo, J. (2000). Spring frosts in deciduous fruit trees - morphological damage and flower hardiness, Scientia Horticulturae, 85(3), 155-173. DOI: 10.1016/S0304-4238(99)00150-8. 